

\title{
Students' Interest toward Learning Activities Based-on 4Cs Skills in Mathematics Classroom: A Need Analysis Study
}

\author{
Norazlin Mohd Rusdin, Siti Rahaimah Ali
}

To Link this Article: http://dx.doi.org/10.6007/IJARBSS/v9-i6/6153

DOI: $10.6007 /$ IJARBSS/v9-i6/6153

Received: 14 April 2019, Revised: 18 May 2019, Accepted: 08 June 2019

Published Online: 29 June 2019

In-Text Citation: (Rusdin \& Ali, 2019)

To Cite this Article: Rusdin, N. M., \& Ali, S. R. (2019). Students' Interest toward Learning Activities Based-on 4Cs Skills in Mathematics Classroom: A Need Analysis Study. International Journal of Academic Research in Business and Social Sciences, 9(6), 1277-1289.

Copyright: (C) 2019 The Author(s)

Published by Human Resource Management Academic Research Society (www.hrmars.com)

This article is published under the Creative Commons Attribution (CC BY 4.0) license. Anyone may reproduce, distribute, translate and create derivative works of this article (for both commercial and non-commercial purposes), subject to full attribution to the original publication and authors. The full terms of this license may be seen

at: http://creativecommons.org/licences/by/4.0/legalcode

Vol. 9, No. 6, 2019, Pg. $1277-1289$

http://hrmars.com/index.php/pages/detail/IJARBSS

JOURNAL HOMEPAGE

Full Terms \& Conditions of access and use can be found at http://hrmars.com/index.php/pages/detail/publication-ethics 


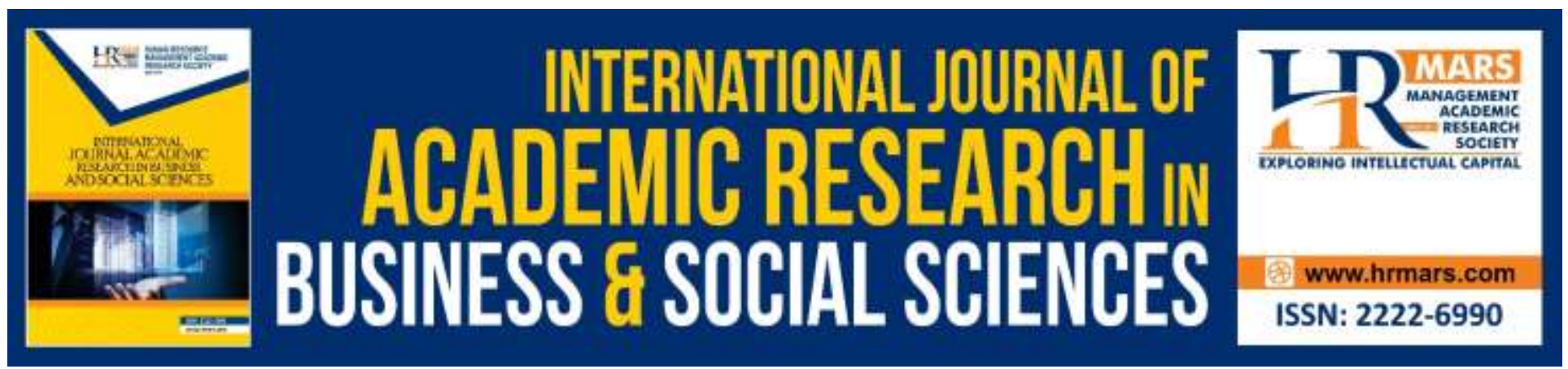

\title{
Students' Interest toward Learning Activities Based- on 4Cs Skills in Mathematics Classroom: A Need Analysis Study
}

\author{
Norazlin Mohd Rusdin, Siti Rahaimah Ali \\ Fakulti Pembangunan Manusia, Universiti Pendidikan Sultan Idris, Tanjung Malim, Perak \\ Malaysia \\ Email: norazlinrusdin@gmail.com, siti.rahaimah@fpm.upsi.edu.my
}

\begin{abstract}
In a study of module development, need analysis should be carried out in order to ensure the module developed will be able to fulfil consumers' needs. Therefore, this study is a part of need analysis study in a research of developing pedagogy module of active learning based on 4Cs skills for Number and Basic Operation in Mathematics (PA4K Module). The 4Cs skills are consist of critical thinking, communication, collaboration and creativity. This study was carried out to identify students' interest toward learning activities based on 4Cs skills in mathematics classroom. 70 of Year Three pupils were involved in this study and they have responded to the questionnaire provided. The findings show in average that pupils agreed at high level to the items related to critical thinking (Mean $=4.38$ ) very high level of interest toward communication (Mean $=4.59$ ), collaboration (Mean $=4.63$ ) and creativity (Mean $=4.51$ ). According to the findings, it is necessary to develop the module where it is useful to be used by teachers as reference and guidance in enhancing teaching practice which is effective for fostering 4Cs skills among the pupils.
\end{abstract}

Keywords: 4cs, Critical Thinking, Communication, Collaboration, Creativity, Teaching and Learning, Mathematics.

\section{Introduction}

In $21^{\text {st }}$ century learning, there are 4 skills (4Cs) should be mastered by pupils namely communication, collaboration, creativity and critical thinking as mentioned in Bulletin of Malaysia Education Transformation No. 4/2015 (Bulletin of Paradigm, 2015). These 4Cs skills also emphasized in education around the world as super skills. It is significantly important to put on efforts on fostering these skills in order to achieve the vision of Pelan Pembangunan Pendidikan Malaysia (PPPM) 20132025 (MMOE, 2013). Recently, Malaysia Ministry of Education (MMOE) and State Education Department of Johor put serious attention on fostering 4Cs skills by providing guidance related to the 
INTERNATIONAL JOURNAL OF ACADEMIC RESEARCH IN BUSINESS AND SOCIAL SCIENCES Vol. 9, No. 6, June, 2019, E-ISSN: 2222-6990 @ 2019 HRMARS

implementation of $21^{\text {st }}$ century learning where the process of instilling 4Cs skills are well emphasized (MMOE, 2017; SEDJ, 2017). Pedagogy and teaching practice of $21^{\text {st }}$ century learning should be enriched by creative, innovative critical thinking and emphasize on problem solving as well as competency in decision making (Osman \& Basar, 2016).

Move along the changing world, pupils need supportive learning environment which promoting motivation, accurate to subject contents and provide opportunity for pupils to learn in $21^{\text {st }}$ century setting where collaboration with peers, teachers and community are expanded (Eduviews, 2008). Creativity among the pupils can be nourished when learning environment offer chances for pupils to communicate new ideas as well as solving complex problems through collective works (Scott, 2015).

Put attention on content standard and learning standard, pupils' previous knowledge, preparing resources and selecting appropriate combination of strategy and skills should be emphasized by teachers (Ariffin \& Yunus, 2017). Teachers should put priority on planning and implementing $21^{\text {st }}$ century education through interactive, effective and attractive pedagogical practice (Ariffin \& Yunus, 2017).

\section{Needs Analysis in Module Development Research}

This study was carried out to gain information regarding to pupils of Year Three interest toward activities based on 4cs skills in mathematics classroom. In design and development research on module, need analysis study is a part of process should be implemented. Need analysis phase is the first phase in the research which is important to obtain information in context and environment of what a researcher going to study (Siraj et al., 2013).

According to Richey and Klein (2007) need analysis is necessary to determine the specification of a product. Need analysis phase provides information which is crucial and will be used in the next phases of designing and developing module (Gagne et al., 2005). The information also used in determining the content of instructional resource optimally as well as deciding the methods on how to convey instruction (Richey \& Klein, 2007). Therefore, needs analysis study play important role in identifying what kind of product is the most appropriate to be developed in order to foster 4Cs skills through pedagogical approach that applying active learning. The findings and suggestions collected in this phase will be used in designing and developing phases (DeWitt, 2010).

Refer to this research context, needs analysis study was carried out at the beginning of module development research to ensure that pupils have interest toward 4Cs skills so that the module will be able to fulfil pupils' interest, increasing motivation and support their learning.

Researches carried out by Ujang (2016), Ahmad (2017) and Ibrahim (2017) show the importance of developing module in enhancing pedagogy as well as teaching and learning process. 
INTERNATIONAL JOURNAL OF ACADEMIC RESEARCH IN BUSINESS AND SOCIAL SCIENCES Vol. 9, No. 6, June, 2019, E-ISSN: 2222-6990 @ 2019 HRMARS

\section{Problem Statement}

Pupils need critical thinking, communication, collaboration and creativity skills to successfully adapt in global competition environment. Therefore, school should integrate these 4Cs skills in teaching and learning. These skills should be a part of learning and facilitating process to ensure the effectiveness of high quality learning that fulfil the needs of $21^{\text {st }}$ century education. Fostering $4 \mathrm{Cs}$ skills in education represent great learning environments that possess capability to produce pupils with the skills which are needed to be successful future citizen and leader.

In order to nourish every pupil with $21^{\text {st }}$ century skills, teachers need to face great challenge since there are a number of $21^{\text {st }}$ century skills to be fostered in limited duration of teaching period (Yunos, 2015). The attempts of fostering $21^{\text {st }}$ century skills among the pupils become difficult due to distinguish previous knowledge, interest, motivation as well as learning style among the pupils (Iberahim, Mahmud \& Mohamad, 2017). Even teachers show only moderate level of understanding toward implementation of $21^{\text {st }}$ century learning and assessment (Ambotang \& Gobalakrishnan, 2017). Otherwise, this understanding is important since it influences teachers' ability in making decision and practising teaching that fulfil this century learning setting and demand (Carlgren, 2013).

According to Tinzmann et al. (1990) and Razak (2013), teaching and learning under traditional method require teachers to convey knowledge as many as possible and it can be done easily by teachers since most of the teachers have deep content knowledge and skilful enough to carry out this responsibility. In the order hand, teachers are found to face difficulties in implementing 21st century learning since there are needs to create and evaluate an environment of knowledge which encompass individual experience, language, strategy and culture to guide pupils toward effective learning situations (Razak, 2013). How easy traditional method is compared to the challenging 21st century learning lead teachers to stay with conservative teaching practice. This situation may retard the vision and mission of national education to produce quality generation.

Traditional teaching approach which emphasizes more on memorizing activities and process or just applying simple procedures may not assist the development of pupils' critical thinking skill (Scott, 2015). In traditional teaching with passive teaching approach, pupils are depend so much on the teacher as authority and lead to limited pupils intellectual engagement. Since pupils just jot down notes and complete worksheet individually, they also passive socially and physically (Edwards, 2015).

Adaptation and application of 4Cs skills seldom occur in the process of learning mathematics and consequently, pupils are found not to be able to utilize critical thinking skill in solving problem in real life context (Khalil \& Osman, 2017). Therefore, teachers should take initiative to implement learning that encourage curiosity, construct imagination, creativity and evaluating skill (Partnership for $21^{\text {st }}$ Century Skills, 2010). Pupils with these skills supposed to be better when tolerate to diversity of views, explore new knowledge, articulate thoughts as well as show their own feelings and understand perspectives of others. Furthermore, pupils will show ability in mastering communication and collaboration skills at the best level. 
Practice of fostering 4Cs skills that carried out by most of the teachers is not effective enough to produce pupils who master 4Cs skills at excellent level. Finding of this study will show a clearer vision to the teachers about pupils' interest toward activities based on 4Cs skills in mathematics class. So that, teachers in general and mathematics teachers in specific will be able to move toward fostering 4Cs skills efficiently and effectively

There are needs to take initiative to provide support and assist teachers in implementing $21^{\text {st }}$ century learning as needed. This fact is match to the finding carried out by Namsone et al. (2016) as they found that teachers reach a better level of understanding after they were provided with a model of professional development as a guide. Intervention program such as seminar-workshop should be implemented consistently to meet diversity of teachers' needs (Tan, Teresa \& Rodriguez, 2016). This study suggest to develop a pedagogical module based on 4Cs skills where the module will be useful as teachers reference and also can be used as a material for workshop to enhance pedagogy practice among teachers.

\section{Objective of Study}

There are four objectives of this study consist of

i. Identify level of pupils' interest toward activities based on communication skill in mathematics class.

ii. Identify level of pupils' interest toward activities based on collaboration skill in mathematics class.

iii. Identify level of pupils' interest toward activities based on creativity in mathematics class.

iv. Identify level of pupils' interest toward activities based on critical thinking in mathematics class.

\section{Respondents of Study}

In this study, purposive sampling was applied where selection of respondents was carried out based on researcher's knowledge ang purpose of the study (Idris, 2010). Selected respondents were representing the population of the study (Idris, 2010; Richey \& Klein, 2007). This study involves 70 of Year Three pupils from a primary school from in Perak.

\section{Instruments of Study}

This study utilized a questionnaire consist of 16 items based on 4Cs skills which is there were 4 items for each skill as shown in Table 1.

Table 1. Distribution of number of items according to skill

\begin{tabular}{ll}
\hline Skill & Number of Item \\
\hline Critical thinking & 4 \\
Communication & 4 \\
Collaboration & 4 \\
Creativity & 4 \\
\hline Total & 16 \\
\hline
\end{tabular}


In order to ensure the instrument can be used in this study, the validity and reliability value of the questionnaire has to be determined first. A number of experts get involved in validating a questionnaire to ensure accuracy of the item contents (Fraenkel \& Wallen, 2012; Akib \& Ghafar, 2015). Four experts were involved in this validation test where three of them validate the construction of the items while another one expert was a linguistic expert who make sure the language structure of the items were appropriate and accurate. Appointments of the three experts are based on Stoner, Perrewe and Hofacker (2011) as they appointed 2 experts to evaluate the items that they constructed by themselves. Criteria of experts involved in this study are described in Table 2 below.

Table 2. Validation of questionnaire used in needs analysis phase

\begin{tabular}{|l|l|}
\hline Instrument & Number of Experts \\
\hline Questionnaire on pupils' interest & Total number of experts: 4 orang \\
toward activities based on 4Cs skills in & A mathematics teacher with more than 10 years \\
mathematics class & teaching experience \\
& An experienced mathematics teacher with master's \\
& degree academic qualification \\
& A head panel of mathematics in a primary school \\
& A Malay language teacher with more than 10 years \\
& teaching experience \\
\hline
\end{tabular}

Before the questionnaire has been used, internal consistency of the items was examined in a pilot study where 30 pupils have got involved. Data from pilot study were analysed by using Statistical Package for the Social Sciences (SPSS) to determine Cronbach' alpha value. Cronbach' alpha value of 0.7 or above indicates that the internal consistency of the items is acceptable (Taber, 2018; Tavakol \& Dennick, 2011). Table 2 shows Cronbach's alpha value of the instrument in overall.

Table 3. Cronbach's Alpha value of instrument related to pupils' interest toward 4Cs skills

\begin{tabular}{ll}
\hline Number of Item & Cronbach's Alpha \\
\hline 16 & 0.825 \\
\hline
\end{tabular}

Cronbach's alpha value for the whole 16 items is 0.825 as shown in Table 3 indicates that this questionnaire has acceptable internal consistency. Therefore, the instrument can be used in the real study. The instrument used was applying 5-Point Likert scale where each point represent certain level of agreement as shown in Table 4. 
INTERNATIONAL JOURNAL OF ACADEMIC RESEARCH IN BUSINESS AND SOCIAL SCIENCES Vol. 9, No. 6, June, 2019, E-ISSN: 2222-6990 @ 2019 HRMARS

Table 4. 5-Point Likert Scale

\begin{tabular}{ccccc}
\hline 1 & 2 & 3 & 4 & 5 \\
\hline Very Disagree & Disagree & Neutral & Agree & Very Agree \\
\hline
\end{tabular}

\section{Findings}

Findings of the study were clarified in two main aspect which first, demography of respondents and second, pupils' interest toward activities based on 4Cs skills in mathematics class.

\section{Demography of Respondent}

This study has involved 70 of Year Three pupils consist of male and female pupils from a primary school in Kinta Utara District, Ipoh, Perak. Demography of respondents in this study is represented in Table 5.

Table 5. Frequency distribution of respondents according to gender

\begin{tabular}{cc}
\hline Gender & Frequency (Percentage) \\
\hline Male & $39(55.7 \%)$ \\
Female & $31(44.3 \%)$ \\
\hline Total & $70(100.0 \%)$ \\
\hline
\end{tabular}

According to Table 5, the 70 respondents involved were consist of 39 (55.7\%) male and 31 (44.3\%) female pupils.

\section{Needs Analysis Regarding to Pupils' Interest towards 4Cs Skills in Mathematics Classroom}

Analysis on pupils' interest toward activities based on 4Cs skills has been done according to each skills respectively. The analysis has applied descriptive analysis where mean and standard deviation of each item has been calculating by using SPSS Version 16. Mean values gained were interpreted by utilising interpretation on mean value derived by Torrefranca (2017).

Table 6. Interpretation of Mean Value

\begin{tabular}{|c|c|}
\hline Mean Value & Interpretation \\
\hline $1.00-1.49$ & Very poor \\
$1.50-2.49$ & Poor \\
$2.50-3.49$ & Moderate \\
$3.50-4.49$ & High \\
$4.50-5.00$ & Very high \\
\hline
\end{tabular}

\section{Pupils' Interest toward Activities Based on Communication in Mathematics Class}

Analyses on pupils' interest toward activities based on communication skill were shown in Table 7. 
INTERNATIONAL JOURNAL OF ACADEMIC RESEARCH IN BUSINESS AND SOCIAL SCIENCES Vol. 9, No. 6, June, 2019, E-ISSN: 2222-6990 (C) 2019 HRMARS

Table 7. Mean scores and interpretation related to pupils' interest toward activities based on communication skill

\begin{tabular}{|l|c|c|c|}
\hline \multicolumn{1}{|c|}{ Statement } & $\begin{array}{c}\text { Mean } \\
\text { (M) }\end{array}$ & $\begin{array}{c}\text { Standard } \\
\text { Deviation } \\
\text { (SD) }\end{array}$ & $\begin{array}{c}\text { Interpretatio } \\
\mathbf{n}\end{array}$ \\
\hline S1. I like sharing ideas with friend & 4.53 & 0.776 & Very high \\
\hline S2. I like listening to friends' ideas & 4.63 & 0.718 & Very high \\
\hline S3. I like to present my answer to others & 4.07 & 1.143 & High \\
\hline S4. I like to get involved actively in mathematics class & 4.33 & 0.884 & High \\
\hline Average & 4.59 & 0.880 & Very high \\
\hline
\end{tabular}

For the items S1 to S4 which are statements related to communication skill, pupils gave very high level of agreement toward statement "like sharing ideas with friends ( $M=4.53: S D=0.776)$ and "like listening to friends' ideas" ( $M=4.63)$. Pupils stated their agreement at high level for the other two statement related to "like to present my answer to others" ( $M=4.07$; SD $=1.143$ ) and "like to get involved actively in mathematics class" ( $M=4.33$; SD $=0.884)$. In overall, pupils' agreement toward activities based on communication skill are very high $(M=4.59 ; S D=0.880)$.

\section{Pupils' Interest toward Activities Based on Creativity in Mathematics Class}

Analyses on pupils' interest toward activities based on creativity were shown in Table 8.

Table 8. Mean scores and interpretation related to pupils' interest toward activities based on creativity

\begin{tabular}{|l|c|c|c|}
\hline \multicolumn{1}{|c|}{ Statement } & $\begin{array}{c}\text { Mean } \\
\text { (M) }\end{array}$ & $\begin{array}{c}\text { Standard } \\
\text { Deviation } \\
\text { (SD) }\end{array}$ & $\begin{array}{c}\text { Interpretatio } \\
\mathbf{n}\end{array}$ \\
\hline S5. I like to generate new ideas in mathematics class & 4.63 & 0.556 & Very high \\
\hline $\begin{array}{l}\text { S6. I like to use different strategy in calculating } \\
\text { answer }\end{array}$ & 4.40 & 0.855 & High \\
\hline S7. I like activity of producing creative product & 4.83 & 0.461 & Very high \\
\hline S8. I like brainstorming activities & 4.17 & 0.791 & High \\
\hline Average & 4.51 & 0.663 & Very high \\
\hline
\end{tabular}


INTERNATIONAL JOURNAL OF ACADEMIC RESEARCH IN BUSINESS AND SOCIAL SCIENCES Vol. 9, No. 6, June, 2019, E-ISSN: 2222-6990 (C) 2019 HRMARS

Items S5 to S8 were related to creativity skill. For creativity skill, pupils were very highly agree toward statements related to "like to generate new ideas in mathematics class" ( $M=4.63 ; \mathrm{SD}=0.556)$ and "like activity of producing creative product" ( $M=4.83$; $S D=0.461)$. In the other hand, pupils were agree at high level that they "like to use different strategy in calculating answer ( $M=4.40 ; S D=0.855$ ) and "like brainstorming activities" $(M=4.17$; $S D=0.791)$. Average of mean value $(M=4.51 ; S D=$ 0.663 ) indicate that pupils' agreement toward activities based on creativity were very high.

\section{Pupils' Interest Toward Activities Based on Collaboration in Mathematics Class}

Analysis on pupils' interest toward activities based on collaboration skill is represented in Table 9.

Table 9. Min Scores and Interpretation on Pupils' Interest toward Activities Based on Collaboration Skill in Mathematics Class

\begin{tabular}{|c|c|c|c|}
\hline Statement & $\begin{array}{c}\text { Mean } \\
(\mathrm{M})\end{array}$ & $\begin{array}{c}\text { Standard } \\
\text { Deviatio } \\
n \\
\text { (SD) }\end{array}$ & $\begin{array}{c}\text { Interpretatio } \\
\mathbf{n}\end{array}$ \\
\hline S9. I like to work in group activities. & 4.80 & 0.551 & Very high \\
\hline $\begin{array}{l}\text { S10. I like to help my friend within group in } \\
\text { understanding mathematics lesson. }\end{array}$ & 4.57 & 0.679 & Very high \\
\hline S11. I like to tolerate with friends. & 4.37 & 0.765 & High \\
\hline S12. I like the product produced through group work. & 4.77 & 0.430 & Very high \\
\hline Average & 4.63 & 0.580 & Very high \\
\hline
\end{tabular}

Items S9 to S12 were elements of collaboration skill. Pupils show very high level of agreement toward three statements related to "like to work in group activities" ( $M=4.80 ; S D=0.551$ ), "like to help my friend within group in understanding mathematics lesson" ( $M=4.57$; SD =0.679) and "like the product produced through group work" $(M=4.77 ; S D=0.430)$. Pupils were highly agree that they "like to tolerate with friends" ( $M=4.37 ; S D=0.765)$. In average, pupils were very highly that they like activities based on collaboration skills in mathematics class $(M=4.63 ; S D=0.580)$.

\section{Pupils' Interest toward Activities Based on Critical Thinking in Mathematics Class}

Analyses on pupils' interest toward activities based on critical thinking are as shown in Table 10. Table 10: Mean scores and interpretation on pupils' interest toward activities based on critical thinking in mathematics class 
INTERNATIONAL JOURNAL OF ACADEMIC RESEARCH IN BUSINESS AND SOCIAL SCIENCES Vol. 9, No. 6, June, 2019, E-ISSN: 2222-6990 @ 2019 HRMARS

\begin{tabular}{|c|c|c|c|}
\hline Statement & $\begin{array}{l}\text { Mean } \\
\text { (M) }\end{array}$ & $\begin{array}{c}\text { Standard } \\
\text { Deviation } \\
\text { (SD) }\end{array}$ & $\begin{array}{l}\text { Interpretatio } \\
\mathbf{n}\end{array}$ \\
\hline S13. I like to solve mathematics problem. & 4.40 & 0.894 & High \\
\hline $\begin{array}{l}\text { S14. I like to search for information from various } \\
\text { sources. }\end{array}$ & 4.63 & 0.669 & Very high \\
\hline S15. I can state reason for the answer I choose. & 4.10 & 0.885 & High \\
\hline $\begin{array}{l}\text { S16. I like reasoning activities such as compare and } \\
\text { contrast as well as classify. }\end{array}$ & 4.37 & 0.809 & High \\
\hline Average & 4.38 & 2.650 & High \\
\hline
\end{tabular}

Critical thinking was represented by items S13 to S16. Pupils show agreement at very high level toward only one statement instead of four, which is "like to search for information from various sources" ( $M=4.63 ; S D=0.669)$ and however choose agreement ay high level for the other three statements related to "like to solve mathematics problem" ( $M=4.40 ; S D=0.894)$, "can state reason for the answer I choose" ( $M=4.10 ; S D=0.885)$ and "like reasoning activities such as compare and contrast as well as classify" ( $M=4.37 ; S D=0.809)$. Average mean value shows that pupils highly agree they like activities based on critical thinking $(M=4.38 ; S D=2.650)$.

In summarising here, pupils show high agreement on critical thinking and very high agreement on communication, collaboration and creativity skills regarding to their interest toward activities based on 4Cs skills.

\section{Discussion}

Findings of this study show that pupils have high level of interest toward activities based on 4Cs skills in mathematics class. This finding is supported by the results of researches carried out by Yunos (2015), Sander (2016) and Iberahim, Mahamod and Mohamad, (2017) where they found there were relationship between pupils' interest toward learning and 21st century skills.

This interest should be restraint and nourished in order to enable pupils possess learning experience that reinforce 4Cs skills among pupils until they are able to apply them in real world life. According to Iberahim, Mahamod and Mohamad (2017), applying various meaningful techniques and approaches in learning process seemed to be able to maintain pupils' interest and motivation. It brings meaning that teachers cannot stick to traditional teaching method (Azmi \& Nurzatulshima, 2017) and abandon the implementation of 21st century learning based on 4Cs skills. Otherwise, teachers should work on paradigm shift and chance teaching and learning practice in the classrooms as well as take challenge toward fostering 4Cs skills by planning and implementing activities that are creative, pupil-centred as well as focusing on thinking skills (Salehudin, Hamid, 2017). 
INTERNATIONAL JOURNAL OF ACADEMIC RESEARCH IN BUSINESS AND SOCIAL SCIENCES

Vol. 9, No. 6, June, 2019, E-ISSN: 2222-6990 @ 2019 HRMARS

\section{Conclusion}

According to high level of pupils' interest toward activities based on 4Cs skills, it can be concluded here that development of PA4K module should be carried out. There in a enormous needs toward development of a module based on 4Cs skills in teaching and learning mathematics as a guide for mathematics teachers to ensure the process of fostering 4Cs skills can be done effectively. Furthermore, assessment on pupils' performance regarding to 4Cs skills can be carried out in authentic ways. Therefore, in the next phase of research, focus wikl be put on developing a module that applying active learning activities and fostering 4Cs skills for topics of Numbers and Basic Operation and this module will be known as PA4K Module.

\section{References}

Ahmad, Z. (2017). Development of Flipped Classroom Pedagogical Module Based $\mathrm{n}$ Reflective Learning for Premier Polytechnic. Doctor Philosophy Thesis. Faculty of Education, Universiti of Malaya, Kuala Lumpur.

Akib, E., \& Ghafar, M. N. A. (2015). The Validity and Reliability of Assessment for Learning (AfL). Education Journal. Vol. 4, No. 2, pp. 64-68. doi: 10.11648/j.edu.20150402.13.

Ambotang, A. S., \& Gobalakrishnan, S. (2017). Teachers' Integrity and Readiness in Implementing School-Based Assessment. International Journal of Education, Psychology and Counseling, 2(4), 1-22. elSSn:0128-164X.

Ariffin, N. A., \& Yunus, F. (2017). Preschool Teachers' Readiness in Implementing High Order Thinking Skills in Teaching and Learning.

Azmi, M. N., \& Nurzatulshima. (2017). Infusing High Order Thinking Skills: Teachers' Readiness in Teaching and Learning of Primary School Design and Technology Subject. International Research Journal of Education and Sciences (IRJES). Vol.1 Special Issue 1 (Malay).

Bulletin of Paradigm. (April, 2015). The Features of $21^{\text {st }}$ Century Learning. Bulletin of Malaysia Education Transformation. Plan of Malaysia Education Development 2013-2025, p.2.

BUSD. Berryssa Union School DistrTMK. (2016). $21^{\text {st }}$ Century Learning and the 4Cs. BUSD Education Services.

Carlgren, T. (2013). Communication. Critical Thinking, Problem Solving: A Suggested for All High School Students in the $21^{\text {st }}$ Century. Interchange, 44, 63-81.

CCSS. Common Core State Standard. (2014). A Commitment to Student Success: Preparing America's Students for College and Career. Dicapai dari https://www.svsd410.org/cms/lib/WA01919490/Centricity/Domain/31/Parent\%20CCSS\%20 Presentation.pdf

DeWitt, D. (2010). Development of collaborative mLearning module on nutrition for Form Two students. Doctor Philosophy Thesis. Faculty of Education, Universiti of Malaya, Kuala Lumpur.

Eduviews. (2008). Teaching in The $21^{\text {st }}$ Century: A Review of the issues and Changing Models in the Teaching Profession, retrieved from http://www.blackboard.com.

Edwards, S. (2015). Active Learning in the Middle Grades. Middle School Journal, May 2015, 26-32.

Fraenkel, F. J., \& Wallen, N. E. (2009). How to Design and Evaluate Research in Education. Qualitative Research (7th ed.). McGraw-Hill Higher Education. 
INTERNATIONAL JOURNAL OF ACADEMIC RESEARCH IN BUSINESS AND SOCIAL SCIENCES

Vol. 9, No. 6, June, 2019, E-ISSN: 2222-6990 @ 2019 HRMARS

Gagne, M. R., Wager, W. W., Golas, K. C., \& Keller, J. M. (2005). Principles of instructional design (5th ed.).

Belmont, CA: Wadsworth.

Iberahim, A. R., Mahamod, Z., \& Mohamad, W. M. R. M. (2017). 21 $1^{\text {st }}$ Century Learning and the Influence of Attitude, Motivation and Achievements Malay Language Secondary School Students. Malay Language Education Journal, 7(2), 77-88. ISSN: 2180-4842.

Ibrahim, Z (2017). Development of Graphic Design Learning Module Based on Technology amd Learning Style of Students with Hearing Disabilitiy. Doctor Philosophy Thesis. Faculty of Education, Universiti of Malaya, Kuala Lumpur.

Idris, N. (2010). Research in Education. Kuala Lumpur: McGraw-Hill.

ISTE. International Society for Technology in Education. (2007). ISTE Standards Students. iste.org/standards.

Khalil, N. M. \& Osman, K. (2017). STEM-21Cs Module: Fostering $21^{\text {st }}$ Century Skills through Integrated STEM, K-12 STEM Education, 3(3), 225-233.

MMOE. Malaysia Ministry of Education. (2013). Plan of Malaysia Education Development 2013 - 2025. Retrieved from https://www.moe.gov.my/images/dasar-kpm/PPP/Preliminary-BlueprintBM.pdf.

MMOE. Malaysia Ministry of Education. (2017). 21 $1^{\text {st }}$ Century Learning. Retrieved from http://upa.ipgkda.edu.my/wp-content/uploads/2017/07/PAK21-KPM.pdf.

Namsone, D., Cakane, L., France, I., \& Butkevica, A. (2016). Lesson-based Professional Development as A Way to Help Primary Teachers Teach $21^{\text {st }}$ Century Skills. Proceedings of the ICERI 2016 Conference. Seville, Spain.

Osman, B. H. A., \& Basar, M. N. (2016). 21 ${ }^{\text {st }}$ Century Teaching and Learning Practice Among Lecturer at Institut Pendidikan Guru Kampus Ipoh. Dedication Research Journal. Jilid 10.

P21. Partnership for $21^{\text {st }}$ Century Skills. (2010). $21^{\text {st }}$ Century Skills Map: Math. Dicapai dari http://www.p21.org/storage/documents/P21_Math_Map.pdf

Razak, R. A. (2013). Pembelajaran Berasaskan Penghasilan Cerita Digital Multimedia bagi Menganalisis Novel Bahasa Melayu. Jurnal Pendidikan Malaysia, 38(1), 53-64.

Salehudin, N. N., Hassan, N. H., \& Hamid, N. A. A. (2015). Mathematics and $21^{\text {st }}$ Century Skills: Students' Perspective. Mathematics Education Journal. 3(1), 24-36. ISSN: 2231-9425.

Sanders, S. (2016). Critical and Creative Thinkers in Mathematics Classroom. Journal of Students Engagement: Education Matters, 6(1),19-27.

Scott, C. L. (2015). The Future of Learning 3: What Kind of Pedagogies for the $21^{\text {st }}$ Century? Education Research and Foresight Working Paper, United Nations Educational, Scientific and Cultural Orgnization, 15 Decemcer 2015.

Siraj, S., Alias, N., DeWitt, D., \& Hussin, Z. (2013). Design and Developmental Research:

Emergent Trends in Educational Research. Kuala Lumpur: Pearson Malaysia.

State Education Department of Johor. (2017). Performance Standard of $21^{\text {st }}$ Century Learning for Schools in Johor. Retrieved from www.jpnjohor.moe.gov.my.

Stoner, J., Perrewé, P., \& Hofacker, C. (2011). The Development and Validation of the MultiDimensional Identification Scale (MDIS). Journal of Applied Social Psychology. 41. 1632 - 1658. 10.1111/j.1559-1816.2011.00770.x. 
Taber, K. S. (2018). The Use of Cronbach's Alpha When Developing and Reporting Research Instruments in Science Education. Res Sci Educ, 2018(48), 1273-1296.

Tan, C. S., M. Teresa, and M. Rodriguez. (2016). Readiness and Preparation of Pre-Service Teachers on the $\mathrm{K}$ to 12 Program. International Journal of Research in Engineering, IT and Social Sciences. Vol. 6, Issue 12, 13-19. ISSN 2250-0588.

Tavakol, M., \& Dennick, R. (2011). Making Sense of Cronbach's Alpha. International Journal of Medical Education, 2011(2), 53-55. ISSN:2042-6372.

Tinzmann, M. B. et al. (1990). What is the Collaborative Classroom?. Dicapai dari https://www.researchgate.net/publication/251574844_What_Is_the_Collaborative_Classro om.

Torrefranca, E. C. (2017). Developmental and Validation of Instructional Modules on Rational Expressions and Variations. The Normal Lights, 11(1), 43-73.

Ujang, A. (2016). Development of WebQuest Health Education Learning Module for Pre-Service Teachers of Students with Learning Disabilities. Doctor Philosophy Thesis. Faculty of Education, Universiti of Malaya, Kuala Lumpur.

Yunos, M. (2015). Attitude Realtionship and Students' Perception through Malay Language Learning with $21^{\text {st }}$ Century Skills. Malay Language Education Journal-MyLEJ, 5(2), 22-30. ISSN 21804842. 